\title{
Election tonic for Japanese science funding
}

Tokyo. Japan's government research sector appears likely to win some more money with the expected return to power of the Liberal Democratic Party (LDP) after last week's general election. But there are unlikely to be any radical changes to the administration of science, despite talk by all political parties, during the election campaign, about the need to reform and reduce the size of government ministries and agencies.

The LDP increased its number of seats in the powerful lower house of the Diet (parliament) from 211 to 239 - 12 short of a majority. It seems set to take power alone, without its former coalition partners, the Social Democratic and Sakigake parties. Talks on maintaining the coalition government failed. Instead, the two former coalition partners, which lost many seats in the election, have agreed to continue to cooperate with the LDP on common goals.

But this will put the LDP in a weak position, and it will probably try to gain the support of independent Diet members. It may also be able to persuade some former LDP politicians in the New Frontier Party (Shinshinto) to return to the fold. It seems certain, however, that Ryutaro Hashimoto, the head of the LDP, will be re-elected as prime minister early next month when the Diet reconvenes.

The LDP places top priority on introducing a supplementary budget before the end of the year to spend $¥ 5,000$ billion (US\$45 billion) to help boost the flagging economy. And last week Hashimoto singled out science and technology and research and development as areas that should get some of the extra funds

Although the other parties are lukewarm on the need for a supplementary budget,

\section{IMAGE \\ UNAVAILABLE FOR COPYRIGHT REASONS}

Hashimoto: regards science and technology as key areas to benefit from extra money.

there is broad cross-party support for giving extra money to science and technology. The supplementary budget would add to several others over the past few years that have pumped substantial new funds into government research.

Another beneficiary on the side of science is likely to be the little island of Okinawa at the southern end of Japan. Just before the election, Hashimoto reached an agreement with the governor of Okinawa to pump several billion yen of extra government money into the island in return for cooperation in keeping US military bases on the island. Some of the money is expected to go into new facilities for "tropical research".

Although the Social Democratic Party is pushing for much greater reduction of US military facilities in Okinawa, it is unlikely to oppose the new funds.

Officials in government ministries and agencies will be happy to see the LDP back $\&$ at the helm. In the lead-up to the election, many parties, including the LDP, were promising radical reform of the bureaucracy, which has been blamed for the crisis in the banking system and for the HIV contamination of haemophiliacs. The LDP, however, has traditionally maintained strong links with the administrative wing of government, and any reform it brings will be much less radical than anything proposed by the opposition parties.

But Akito Arima, president of the Institute of Physical and Chemical Research (RIKEN) and a leading campaigner for reform of government research, says there may still be serious discussion on reorganizing the roles of the key science-related ministries. These include the Ministry of International Trade and Industry, the Science and Technology Agency, the Ministry of Health and Welfare, and the Ministry of Education, Science, Sports and Culture.

In its weakened position without coalition partners, the LDP may be forced to listen to calls for reform from opposition parties, such as the new Democratic Party of Japan. One of this party's joint leaders is Naoto Kan, who, as minister of health in Hashimoto's government, exposed his ministry's role in the infection of haemophiliacs with HIV. David Swinbanks

\section{Biologists call on Brussels to bolster basic research}

Munich. A panel of European biologists has urged the European Commission to ensure that basic research receives strong support in the commission's next five-year Framework research programme (FP5). In particular, the panel, which was chaired by François Gros, former director of the Pasteur Institute in Paris, says there is a need for more European-level support for genetics and neuroscience research.

The ad hoc panel, an informal group made up largely of members of the European Science and Technology Assembly (ESTA), an advisory body to the European Commission, was set up earlier this year to advise ESTA on the recommendations that the assembly should make to the commission about support for biology research under FP5.

It presented its conclusions about factors that the commission should consider in setting European priorities for biology to the assembly earlier this month.

The panel's report argues that it is important to include basic research in FP5, which runs from 1998 to 2002 , because its long-term survival is essential for the future of applied research, and it would be a "serious mistake to overlook the interdependence of advances in science and technology".

The biologists warn against rigidly applying the principle of subsidiarity, which prevents the commission from supporting action that can be supported at a national level.

A narrow interpretation of this principle, they say, would exclude European-level support for long-term basic research, as most of this is seen as a national responsibility.

Specific areas that should receive more support, they say, are the creation of scientific networks, allowing the buildingup of international research teams, and the funding of large facilities such as major instruments, laboratories and databases.

Because of their size, scope and expense, such facilities should be accessible to scientists in all European countries. The group also recommends that FP5 should give the commission the opportunity to give additional funds to existing national or European centres of excellence.

The report focuses on the advantages of European-level research in genetics and molecular biology, where the commission has already made considerable investment in infrastructure. It has approved two large grants to establish a European mouse-gene repository at Monterotondo near Rome (EMMA), and four supporting laboratories in France, Sweden, Portugal and Britain.

The repository will house a collection of mutant-mouse strains, which are widely used, for example, as experimental models of human diseases. The commission has also supported the development of the European Bioinformatics Institute (EBI) in Cambridge, a genetic database which is an outstation of the European Molecular Biology Laboratory.

The report says that this type of initiative requires a longer-term commitment than the commission is able to guarantee within its five-year Framework programmes, although it makes no suggestion about how this could be achieved.

Alison Abbott 